\title{
SISTEM INFORMASI GEOGRAFIS PEMETAAN BENCANA ALAM KOTA BREBES MENGGUNAKAN METODE EXTREME PROGRAMMING
}

\author{
Warjiyono'; Sopian Aji $^{2}$; Tri Indah Permesti ${ }^{3}$ \\ Sistem Informasi Akuntansi ${ }^{1}$, Sistem Informasi ${ }^{3}$ \\ Universitas Bina Sarana Informatika ${ }^{1,3}$ \\ www.bsi.ac.id 1,3 \\ warjiyono.wrj@bsi.ac.id ${ }^{1}$, triindahpermesti23@gmail.com ${ }^{3}$ \\ Sistem Informasi² \\ STMIK Nusa Mandiri ${ }^{2}$ \\ www.nusamandiri.ac.id $^{2}$ \\ sopian.sop@nusamandiri.ac.id

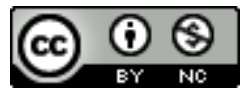

Ciptaan disebarluaskan di bawah Lisensi Creative Commons Atribusi-NonKomersial 4.0 Internasional.

\begin{abstract}
Public service is an activity of service for every citizen and resident for goods, services, and / or administrative services provided by public service providers, namely the Regional Disaster Management Agency (BPBD) of Brebes Regency. The quality of public services must have the principle of openness or transparency, easily accessible, accountability and cling to the principles of efficiency and effectiveness. But in fact the current information and reporting of disasters is still conventional. This study aims to reflect and build a Web-Based Disaster Geographic Information System using Extreme Programming method. The research method uses qualitative methods with descriptive data analysis techniques. Data obtained by observation and interviews. The benefit of this application is to improve services to the Brebes Regional Disaster Management Agency also useful for internal from the Implementing Party or Admin who can manage Disaster Area data online, accurately, and quickly. As well as greatly helping the community to obtain maps of information on disaster-prone areas, the latest disaster information and the community can report directly on disaster events so that the Regional Government can directly handle the disaster.
\end{abstract}

Keywords : Natural Disasters, Regional Mapping, Geographic Information System, ICT

Intisari- Pelayanan publik merupakan kegiatan pelayanan bagi setiap warga negara dan penduduk atas barang, jasa, dan atau pelayanan administratif yang disediakan oleh penyelenggara pelayanan publik yaitu Badan Penanggulan Bencana Daerah
(BPBD) Kabupaten Brebes. Kualitas pelayanan publik harus memiliki prinsip keterbukaan atau transparansi, mudah diakses, akuntabilitas serta berpegang teguh pada prinsip efisiensi dan efektivitas. Tetapi nyatanya saat ini informasi dan pelaporan bencana masih konvensional. Penelitian ini bertujuan untuk merancang dan membangun Sistem Informasi Geografis Pemetaan Bencana Berbasis Web dengan menggunakan metode Extreme Programming. Metode penelitian mengunakan metode kualitatif dengan teknik analisis data deksriptif. Data diperoleh dengan observasi dan wawancara. Manfaat dari aplikasi ini adalah untuk meningkatkan pelayanan pada Badan Penanggulangan Bencana Daerah Brebes juga bermanfaat bagi internal dari Pihak Pelaksana atau Admin yang dapat mengelola data Daerah Bencana secara online, akurat, dan cepat. Serta sangat membantu masyarakat untuk mendapatkan peta informasi daerah rawan bencana, informasi bencana terkini dan masyarakat dapat melaporkan secara langsung kejadian bencana sehingga Pemerintah Daerah dapat langsung untuk menangani bencana tersebut.

Kata Kunci: Bencana Alam, Pemetaan wilayah, Sistem Informasi Geografis, TIK

\section{PENDAHULUAN}

Brebes merupakan kabupaten yang cukup luas di Provinsi Jawa Tengah. Sebagian besar wilayahnya adalah dataran rendah yang dikeliling oleh sungai yaitu sungai Pemali dan sungai Serayu. Bagian barat daya merupakan dataran tinggi (dengan 
puncaknya Gunung Pojok tiga dan Gunung Kumbang), sedangkan bagian tenggara terdapat pegunungan yang merupakan bagian dari Gunung Slamet. Dengan iklim tropis, curah hujan rata-rata 18,94 $\mathrm{mm}$ perbulan (Brebes, 2018). Brebes merupakan daerah penghasil bawang merah dan terkenal dengan sentra penghasil telor asin khas Brebes.

Kabupaten Brebes rawan bencana alam yaitu tanah longsor (Ningtyas, 2015). Selain tanah longsor, bencana banjir merupakan yang paling sering terjadi dan menjadi fokus kewaspadaan, terutama saat musim penghujan (Riyanto, 2017). Rawan longsor terdapat di wilayah Brebes selatan, meliputi Kecamatan Bumiayu, Ketanggungan, Bantarkawung, Larangan, Banjarharjo, Salem, Tonjong, Sirampog, dan Paguyangan (Farhi, 2012). Sedangkan, daerah rawan banjir terdapat di wilayah Brebes utara, antara lain Kecamatan Brebes, Wanasari, Tanjung, Losari, Bulakamba, Jatibarang, serta sebagian wilayah Brebes Selatan (Tayubi, 2018).

Saat ini informasi-informasi daerah yang berpotensi bencana alam di Kabupaten Brebes masih belum mudah diakses oleh masyarakat (Raharjo, 2009). Berdasarkan wawancara dengan kepala Badan Penanggulangan Bencana Daerah (BPBD) Brebes Bapak Ir. Eko Andalas Mucthi menyatakan selama ini informasi bencana masih menggunakan papan pengumuman serta kejadian bencana kurang cepat bisa dilaporkan karena belum tersedianya sistem informasi bencana yang efektif. Sehingga kualitas pelayanan publik belum berhasil. Pelayanan publik merupakan kegiatan pelayanan bagi setiap warga negara dan penduduk atas barang, jasa, dan/atau pelayanan administratif yang disediakan oleh penyelenggara pelayanan publik atau pemerintah daerah ("Undang-Undang Republik Indonesia No. 25 Tahun 2009 Tentang Pelayanan Publik," n.d.). Kualitas pelayanan publik harus memiliki prinsip keterbukaan atau transparansi, mudah diakses, akuntabilitas serta berpegang teguh pada prinsip efisiensi dan efektivitas (Sinambela et al., 2010).

Sistem informasi bencana alam yang dimiliki oleh Pemerintah Daerah rata-rata sangat terbatas, belum mengikuti perkembangan teknologi dan informasi terkini sehingga menghambat arus informasi bencana, padahal sangat penting sistem informasi dan peta bencana saat ini (Nuryanto, 2016). Sistem Informasi geografis diperlukan untuk mempermudah mengetahui daerah secara visual sehingga mempercepat dalam mengambil keputusan (Sasongko, 2016). Penerapan sistem informasi geografis mampu meningkatkan citra kemudahan dalam memgakses suatu informasi (Eldita, 2018).
Tujuan dari penelitian ini adalah merancang dan membangun sistem informasi geografis bencana alam untuk wilayah Brebes berbasis web dengan tampilan mobile responsif menggunakan metode pengembangan sistem yaitu Extreme Programming. Extreme Programming (XP) adalah metodologi pengembangan perangkat lunak ringan, yang menekankan kerja tim, komunikasi, umpan balik, kesederhanaan dan pemecahan masalah (Iacob, 2008). Manfaat dari aplikasi ini akan sangat membantu masyarakat untuk mendapatkan peta informasi daerah rawan bencana, informasi bencana terkini dan masyarakat dapat melaporkan secara langsung kejadian bencana sehingga Pemerintah Daerah dapat langsung untuk menangani bencana tersebut sebagai bentuk peningkatan pelayanan publik.

\section{BAHAN DAN METODE}

Penelitian yang dilakukan meliputi indentifikasi masalah, studi literatur, pengumpulan data, metode extreme programming, kesimpulan dan saran. Adapun tahapan penelitian yang penulis lakukan adalah seperti pada gambar 1 .

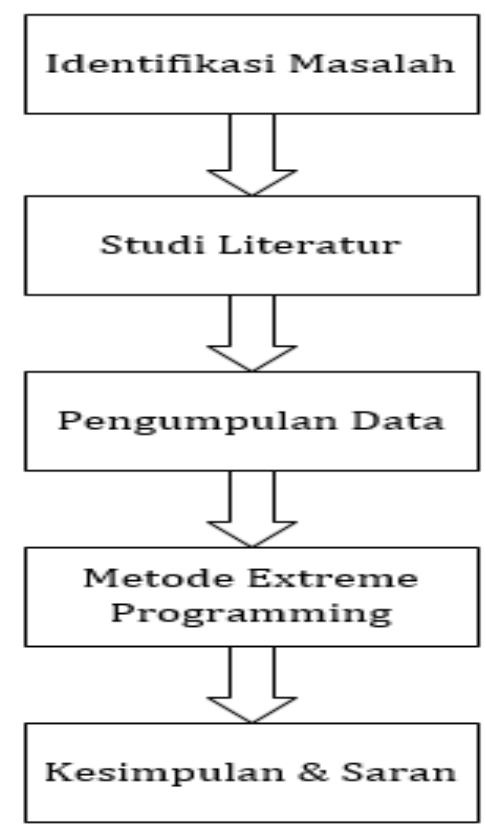

Sumber: (Warjiyono, Aji, \& Permesti, 2018)

Gambar 1. Tahapan Penelitian

Tahapan penelitian sebagai berikut :

1. Identifikasi Masalah

Identifikasi masalah dilakukan wawancara dengan Bapak Ir. Eko Andalas Mucthi, MM. Selaku Kepala BPBD (Badan Penanggulangan Bencana Daerah) Kabupaten Brebes. Hal ini dilakukan untuk mendapatkan informasiinformasi dan permasalahan yang ada seperti 
informasi, data laporan kejadian bencana yang masih menggunakan papan pengumuman kebutuhan akan sistem informasi, sehingga mempermudah dalam melakukan tahapan selanjutnya

2. Studi Literatur

Peneliti melakukan pencarian referensi dari website, jurnal, artikel, skripsi untuk mengetahui teori pendukung penelitian dan penelitian-penelitian terdahulu yang pernah dilakukan. Teori tersebut yaitu Sistem Informasi Geografis (SIG) atau Geografis Information System (GIS), metode pengembangan sistem yaitu Extreme Programming, penelitian-penelitian terdahulu yang terkait dengan penelitian ini.

3. Pengumpulan Data

Peneliti melakukan observasi di PUSDALOPS BPBD (Badan Penanggulangan Bencana Daerah) Kabupaten Brebes. Peneliti mengumpulkan data untuk sekaligus pengambilan data terkait Data Profil Instansi, Data Laporan Bencana, Data Peta Daerah Bencana Kabupaten Brebes dan data lainnya yang diberlukan untuk sistem ini.

4. Metode Extreme Programming (XP)

Tahapan pengembangan sistem XP ini menggunakan 4 (empat) kegiatan atau tahapan yaitu planning, design, coding dan testing hingga perangkat lunak di rilis.

5. Kesimpulan dan Saran

Tahap terakhir adalah menyimpulkan, menyarankan dan rekomendasi hasil penelitian ini untuk BPBD(Badan Penanggulan Bencana Daerah) Kabupaten Brebes.

\section{Extreme Programming}

Extreme Programming merupakan metodologi pengembangan perangkat lunak yang cukup fleksibel untuk mendukung beberapa iterasi teknologi dan menghasilkan prototipe pada waktu yang tepat (Fruhling, Tyser, \& Vreede, 2005). Extreme Programming (XP) merupakan metodologi pengembangan perangkat lunak yang lebih sederhana dan flesibel. Disebut fleksibel karena perubahan-perubahan yang kemungkinan akan terjadi selama pengembangan perangkat lunak dapat dilakukan, walaupun terjadi pada tahap akhir pengembangan sistem.

Extreme Programming memerlukan tim yang kecil sampai menengah, mampu menangani perubahan kebutuhan sistem yang tidak jelas atau perubahan yang sangat cepat (Supriyatna, 2018). Extreme Programming merupakan pendekatan berorientasi objek yang mencakup 4 (empat) kegiatan yaitu perencanaa, desain, pengkodean dan pengujian (Pressman, 2010).

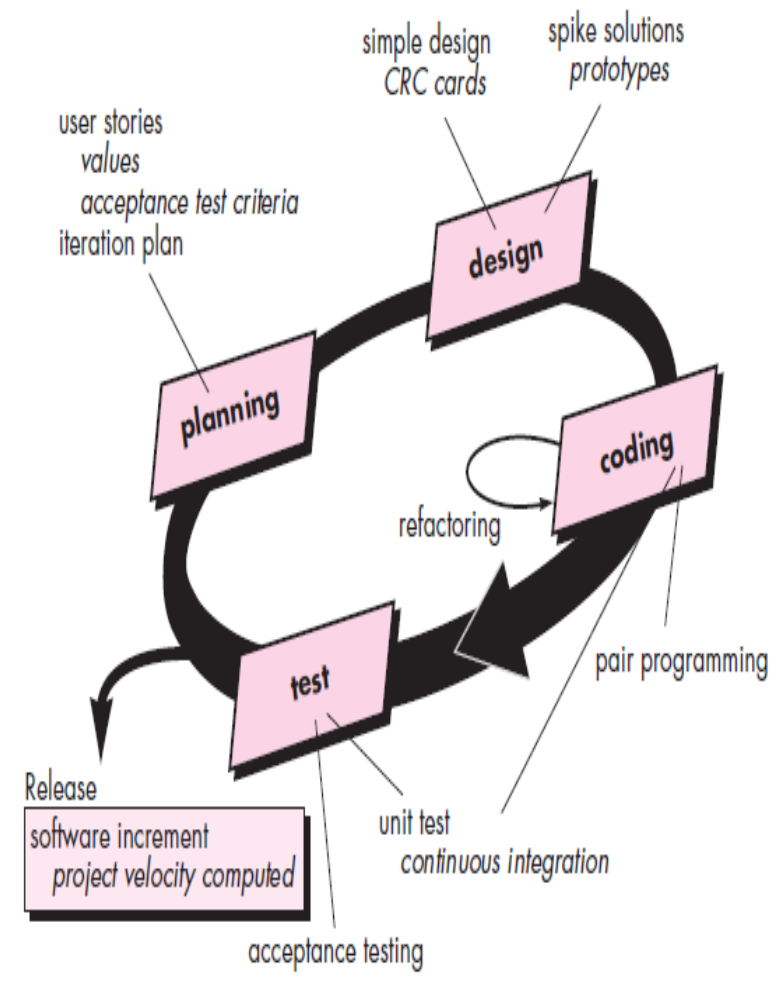

Sumber : (Pressman, 2010)

Gambar 2. Proses Extreme Programming

Adapun tahapan pembangunan aplikasi sistem informasi geografis pemetaan bencana alam Kabupaten Brebes, yaitu :

1. Planning (Perencanaan)

Tahapan ini mengidentifikasi permasalahan yang terjadi sekaligus menganalisa kebutuhan sistem dari pengguna sehingga keluaran sistem yang dibangun benar-benar memenuhi kebutuhan pengguna dengan fitur-fitur utama dan fungsionalitasnya.

2. Design (Perancangan)

Tahapan ini membuat pemodelan sistem, pemodelan basis data untuk menggambarkan hubungan antar data. Pemodelan sistem yang digunakan yaitu Unified Modelling Language (UML) sedangkan pemodelan basis data menggunakan Entity Relationship Diagram (ERD) dan Logical Record Structure (LRS).

3. Coding (Pengkodean)

Tahapan ini adalah implementasi dari perancangan model sistem yang dibuat kedalam kode program. Bahasa pemrograman yang dipakai adalah PHP, HTML, Javascript dan CSS. Untuk implementasi basis data, menggunakan Database Management System yaitu MySQL.

4. Test (Pengujian)

Tahapan ini melakukan pengujian pada fitur dan fungsionalitas dari keseluruhan sistem oleh pengguna sistem dengan menggunakan pengujian blackbox testing untuk menguji 
kesesuaian masukkan dan keluaran dari masing-masing unit sistem. Sehingga fitur sistem dan fungsionalitas dapat berjalan dengan baik dan siap perangkat lunak untuk dirilis.

\section{HASIL DAN PEMBAHASAN}

\section{Planning}

Analisis Kebutuhan di Sistem Informasi Geografis Pemetaan Bencana Berbasis Web Pada Badan Penanggulangan Bencana Daerah Brebes terdapat dua hak akses yaitu hak akses admin dan hak akses pengguna. Kedua pengguna tersebut memiliki interaksi dengan sistem yang berbeda-beda dan memiliki kebutuhan informasi berbeda juga.

Sistem menyediakan login, berita, komentar, pengaduan online serta maps. Peneliti juga membutuhkan perangkat keras dan perangkat lunak untuk menunjang dalam menimplementasikan sistem ini.

\section{Desain}

Use Case Diagram sistem informasi mengenail BPBD(Badan Penanggulan Bencana Daerah) Kabupaten Brebes .

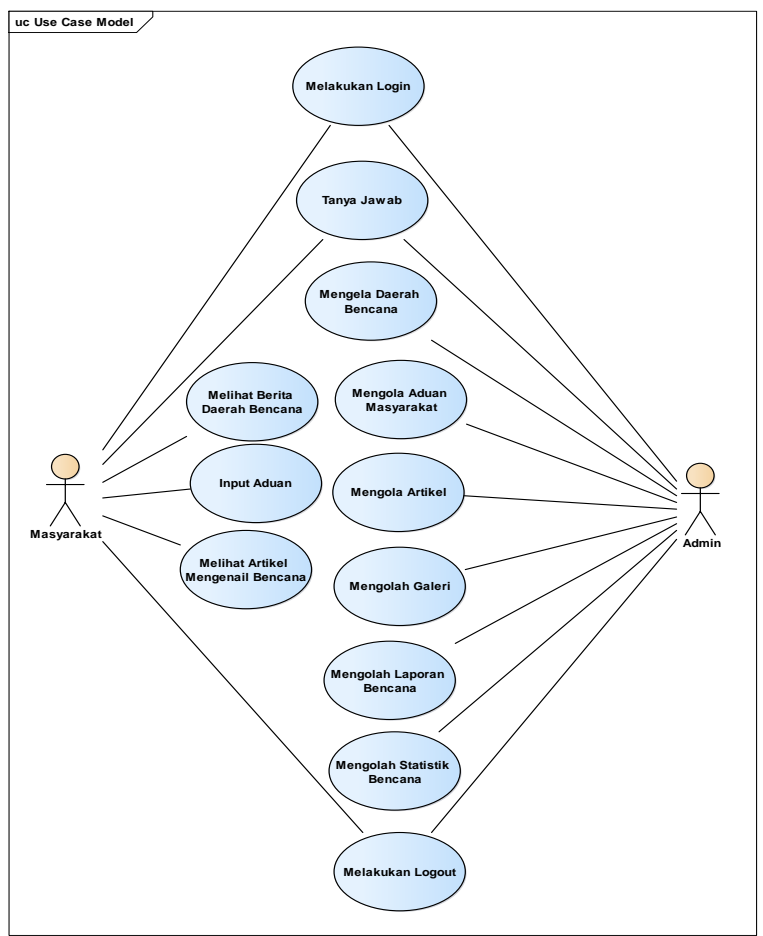

Sumber: (Warjiyono et al., 2018)

Gambar 3. Use case BPBD Kabupaten Brebes

Gambar 3 menjelaskan tentang penggunaan website BPBD (Badan Penanggulan Bencana Daerah) Kabupaten Brebes yang memiliki
2 hak akses yaitu masyarakat dan Admin. Dimana masyarkat dapat melihat daerah bencana, melakukan tanya jawab, iput aduan dan melihat artikel mengenail bencana, sedangkan admin melakukan tanya jawab dengan masyarakat, mengolah daerah bencana, mengolah aduan masyarakat, mengolah artikel, mengolah galeri, mengolah laporan bencana dan mengolah statistik bencana.

Activity Diagram aplikasi pengolahan data pada BPBD(Badan Penanggulan Bencana Daerah) baik pada halaman Masyarakat atau pengunjung dan halaman Admin dari Tim BPBD(Badan Penanggulan Bencana Daerah) Kabupaten Brebes dapat dilihat pada gambar 4 .

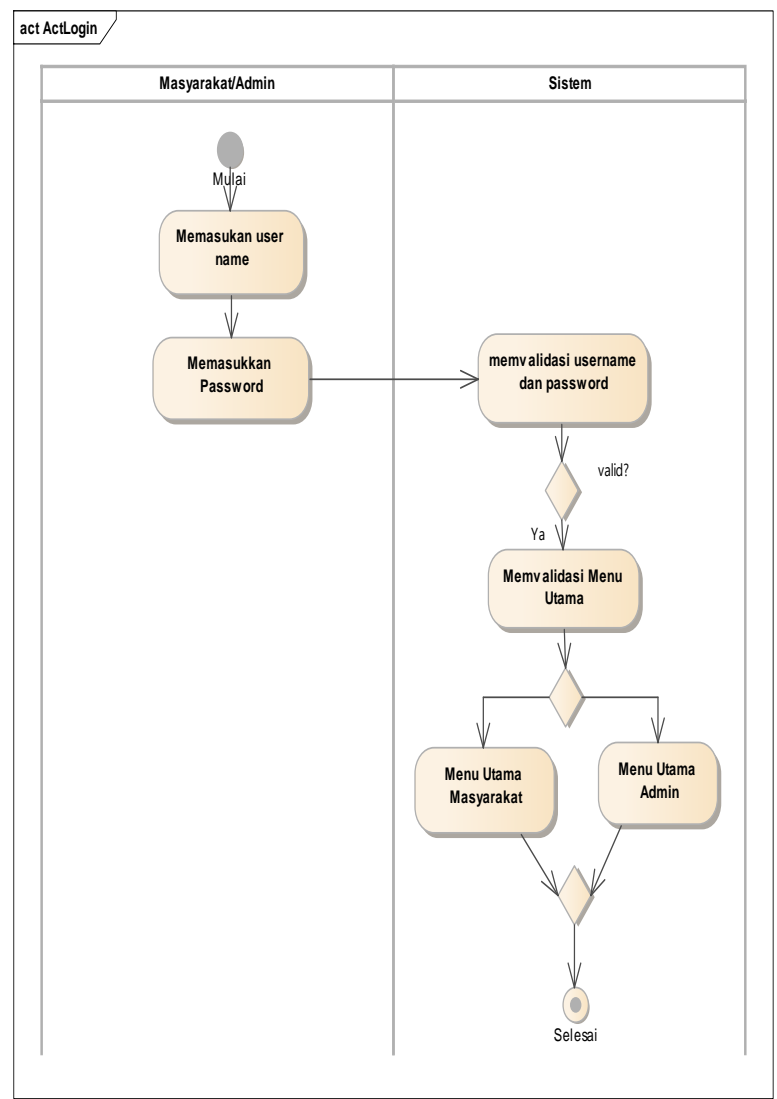

Sumber: (Warjiyono et al., 2018)

Gambar 4. Activity Diagram Login Masyarakat dan Admin

Gambar 4 menggambarkan halaman login baik pada masyarakat maupun admin, pada saat masuk kehalaman utama demi keamanan diminta untuk memasukkan User name dan Password sesuai dengan akun yang telah diberikan. Untuk mendapatkan akun khususnya masyarakat maka masyarakat diminta untuk mendaftar terlebih dulu. 


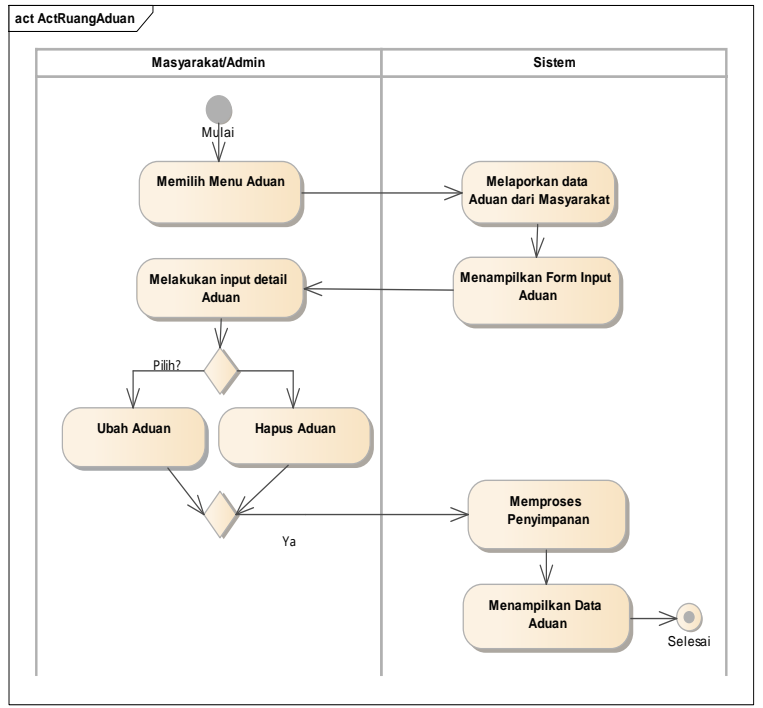

Sumber: (Warjiyono et al., 2018)

Gambar 5. Activity Diagram Aduan Masyarakat

Gambar 5 menjelaskan pada saat masyarakat ingin memerikan aduan kepada tim BPBD(Badan Penanggulan Bencana Daerah) masyarakat diminta untuk memiliki akun, sehingga pada saat melaporkan adun diminta untuk login terlebih dahulu. Pada halaman utama masyakat memilih menu Aduan kemudian sistem akan menampilkan form aduan yang nantinya akan diinput sesuai dengan aduan dari masyarakat berikan. Setelah melakukan penyimpanan aduan dapat diubah kembali atau dihapus.

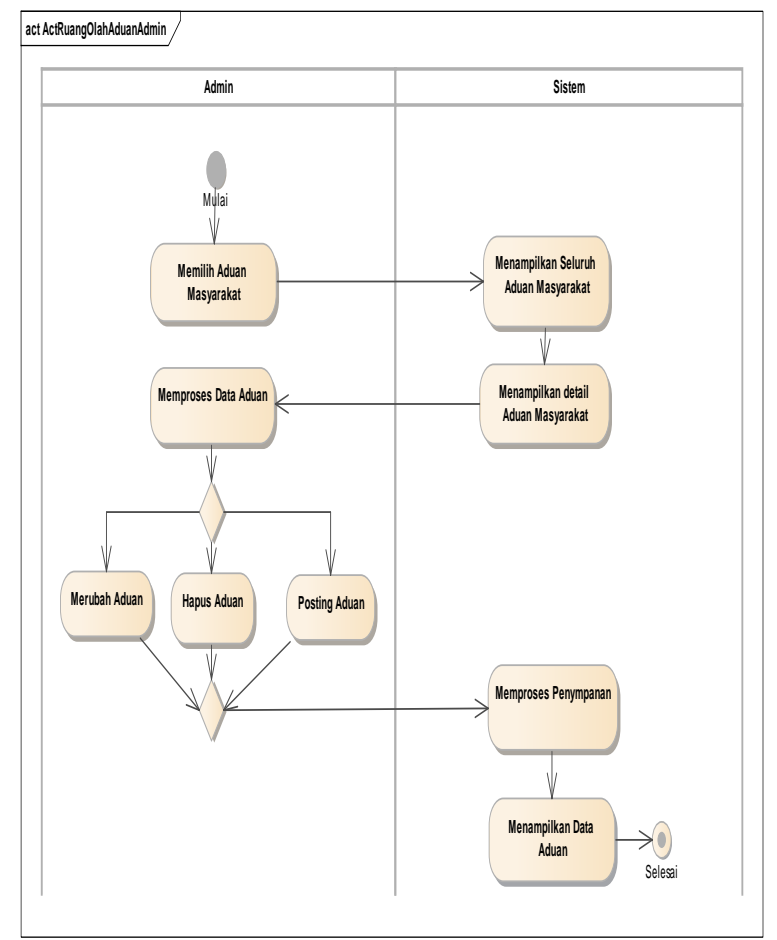

Sumber: (Warjiyono et al., 2018)

Gambar 6. Activity Diagram Halaman Admin Memproses Aduan Masyarakat
Gambar 6 menjelaskan Activity Diagram pada Halaman Admin yaitu pada menu aduan Masyarakat, Admin dapat melihat semua aduan yang diberikan dari Masyarakat. Pada saat memproses aduan maka Tim BPBD (Badan Penanggulan Bencana Daerah) akan menelusuri aduan atau laporan yang diberikan dengan membuktikan aduan yang diberikan dan jika aduan itu benar apa adanya maka admin akan memposting berita aduan tersebut, Namun jika aduan itu tidak benar maka aduan akan dihapus. Pada saat ubah aduan Masyarakat biasanya admin akan merubah kalimat agar mudah di pahami oleh pengunjung web, selain merubah kalimat menentukan titik koordinat pada map sehingga informasi sesuai dengan titik map yang dituju.

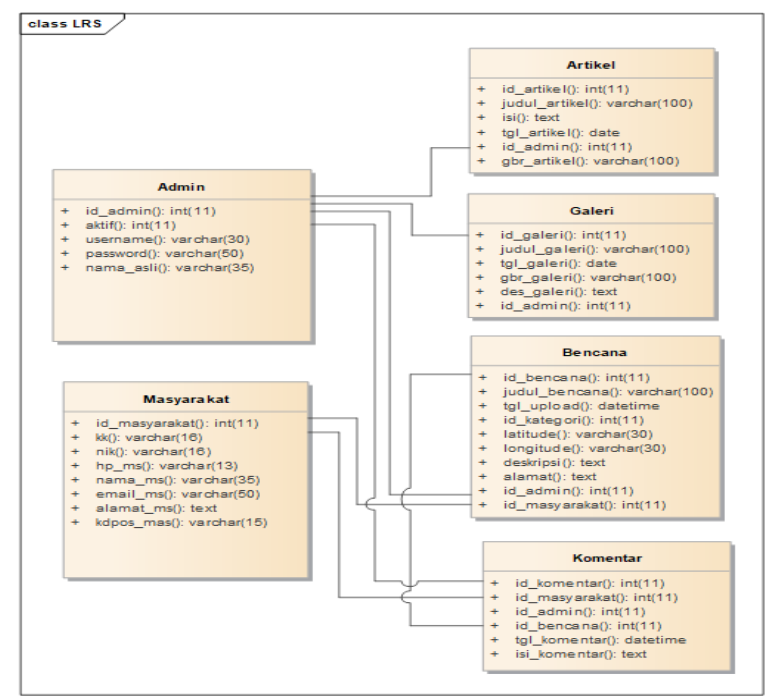

Sumber: (Warjiyono et al., 2018)

Gambar 7. LRS (Logical Record Structure) pada database

Gambar 7 menjelaskan LRS (Logical Record Structure) pada database website Sistem informasi BPBD(Badan Penanggulan Bencana Daerah) Kabupaten Brebes. Yang terdiri dari 6 table yang saling ber-relasi antara tabel satu dengan yang lainnya.

\section{Coding}

Sistem informasi geografis pemetaan bencana alam Kabupaten Brebes berbasis website ini, dibuat dengan menggunakan bahasa pemrograman PHP, HTML, Javascript dan CSS serta database menggunakan MySQL.

Berikut ini tampilan User Interface atau antar muka aplikasi Penanggulangan Bencana Daerah Kabupaten Brebes yang yang telah dibuat.

\section{User Interface Halaman Admin}




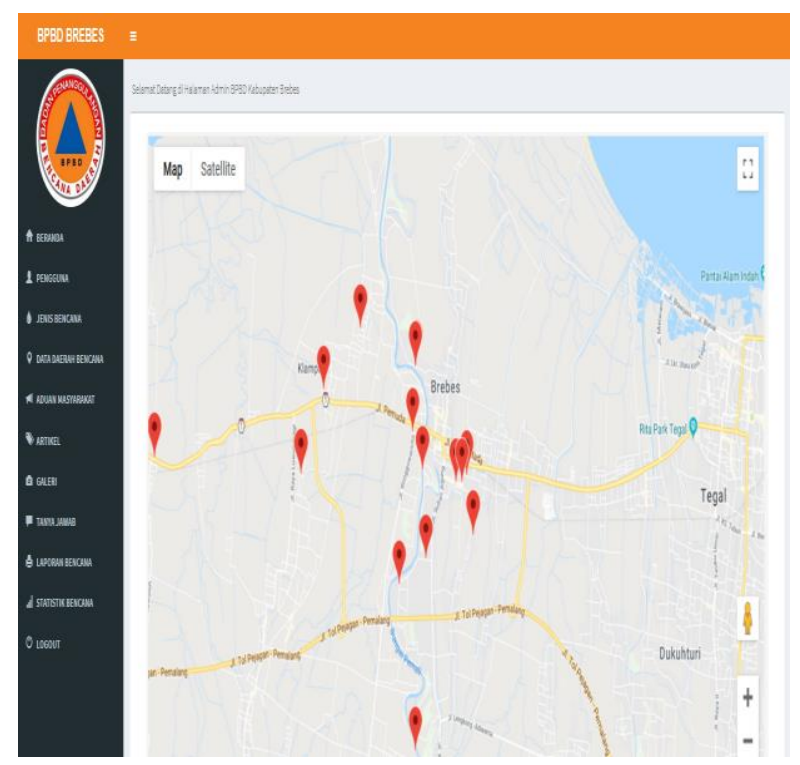

Sumber: (Warjiyono et al., 2018)

Gambar 8. Tampilan Halaman Admin

Pada gambar 8 menunjukan sebuah halaman admin untuk mengolah data mulai dari informasi mengenai bencana atau penanggulanan bencana, artikel-artikel seputar bencana, mengolah data aduan dari masyarakat, foto atau dokumentasi baik pada saat evakuasi bencana atau daerah yang rawan dengan bencana, menggambarkan statistik bencana khususnya di Kabupaten Brebes sampai dengan memberikan titik-titik daerah rawan bencana pada peta sehingga secara visual akan jelas terlihat oleh pengguna.

\section{User Interface Titik Bencana}

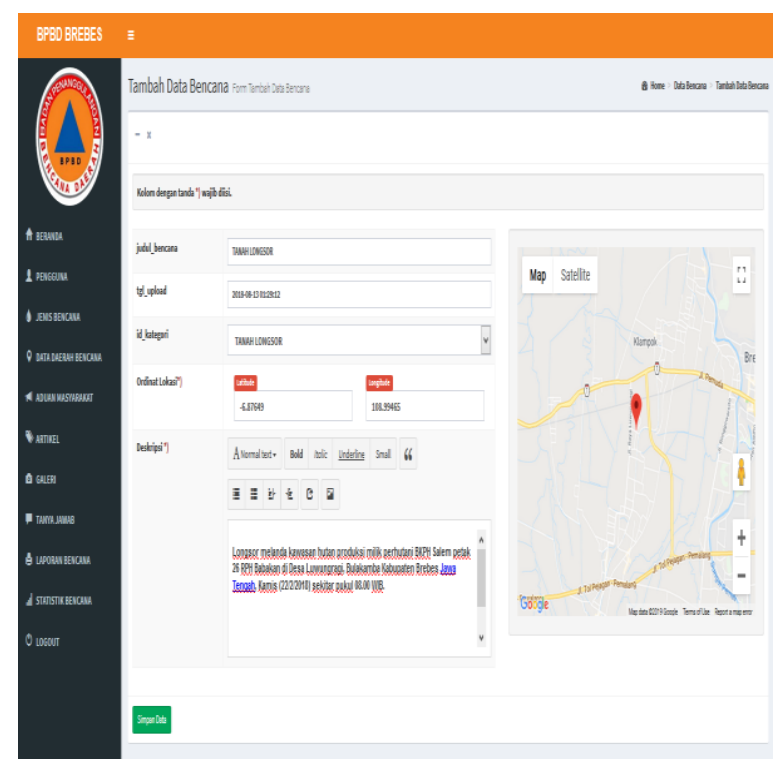

Sumber: (Warjiyono et al., 2018)

Gambar 9. Titik Bencana
Pada gambar 9 merupakan pengaturan titik-titik rawan bencana pada peta, informasi bencana didapat dari Tim BPBD(Badan Penanggulan Bencana Daerah) maupaun dari aduan masyarakat Kabupaten Brebes. Tentunya pada saat menerima aduan masyarakat maka Tim BPBD akan mensurvei kebenaran berita tersebut. Dan jika pemberitaan benar maka admin akan memposting pemberitanya dengan mengolah informasi yang lebih baik dan disertakan titik koordinat pada map sehinggan informasi mudah dilacak keberadaannya.

\section{User Interface Halaman Pengunjung}
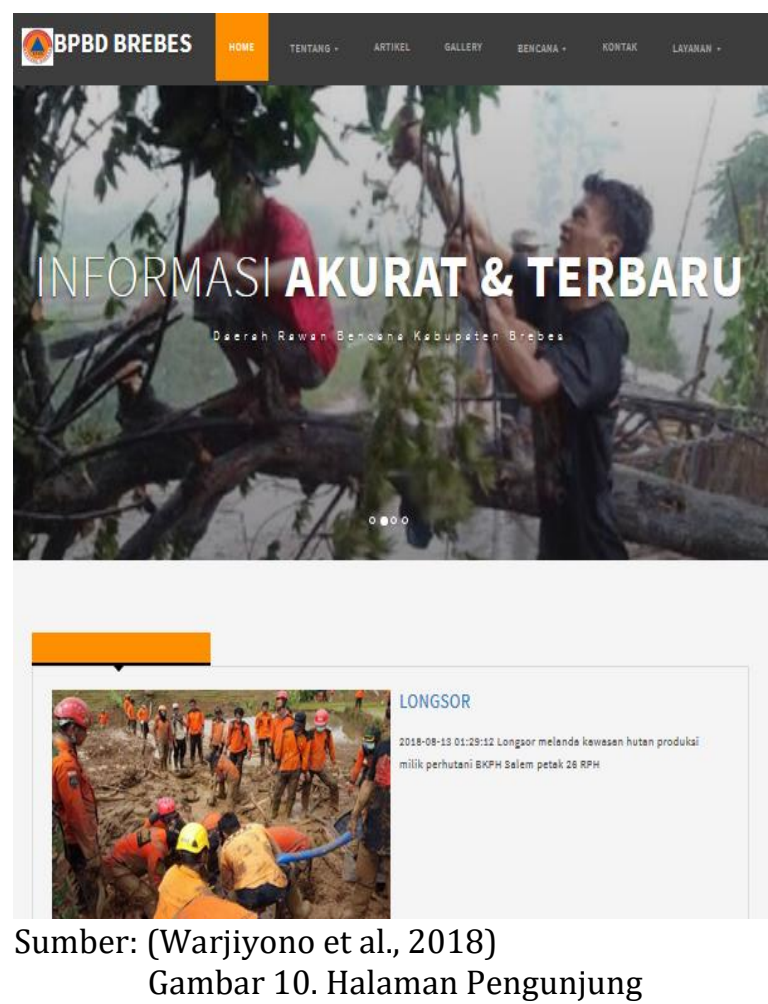

Pada Gambar 10 adalah halaman pengunjung untuk memberikan informasi kepada masyarakat. Informasi yang disampaikan pada web masyarakat atau pengunjung ini adalah informasi mengenai berita tentang bencana atau penanggulangan bencana baik dalam informasi berita atau artikel, foto atau dokumentasi, titik-titik rawan bencana pada peta, selain itu juga masyarakat bisa mengadukan atau menginformasikan daerah yang rawan akan bencana.

\section{Test}

Pengujian black-box, melakukan pengujian perilaku sistem yang berfokus pada persyaratan fungsional perangkat lunak untuk mendapatkan set kondisi input yang sepenuhnya akan 
menjalankan semua persyaratan fungsional untuk suatu program.

Pengujian black-box yang dilakukan di Sistem Informasi Geografis Pemetaan Bencana Alam Kota Brebes dilakukan untuk menemukan kesalahan-kesalahan yang ada seperti error program, kesalahan antarmuka, kesalahan akses database dan kesalahan kinerja.

\section{KESIMPULAN}

BPBD(Badan Penanggulan Bencana Daerah) dengan adanya pemberitaan secara online kepada masyarakat sehingga masyarakat dapat membaca informasi yang disampaikan. Informasi yang disampaikan adalah sebagai berikut dapat menampilkan perkiraan Cuaca, peringatanperingatan titik yang rawan bencana, penanggulangan atau penanganan evakuasi bencana di Kabupaten Brebes.

Selain itu masyarakat pun berperan andil disini dimana masyarakat bisa melakukan aduan yang bertujuan untuk membantu BPBD (Badan Penanggulan Bencana Daerah) dalam mengumpukan informasi sehingga Tim BPBD bisa bergerak cepat mengambil tidakan atau keputusan dalam penanganan bencana. Dengan adanya sistem 2 arah yaitu hak akses masyarakat dan hak akses admin, sehingga informasi yang diberikan data akan segera ter-update dan tepat sasaran sesuai dengan informasi yang diberikan.

Perlunya penelitian lanjut untuk menguji kualitas , menguji penerimaan sistem kepada user sebagai informasi dan masukan guna pengembangan sistem selanjutnya.

\section{REFERENSI}

Brebes, P. K. (2018). Profil Daerah Kabupaten Brebes. Retrieved January 11, 2019, from http://www.brebeskab.go.id/index.php/prof il-daerah/sejarah

Eldita, B. R. (2018). Aplikasi Sistem Informasi Geografis Objek Wisata Berbasis Mobile Android Pada Dinak Kepemudaan, Olahraga dan Pariwisata (Bidang Pariwisata) Kota Metro. Universitas Lampung.

Farhi, Z. (2012). Tingkat Kerentanan dan Indeks Kesiapsiagaan Masyarakat Terhadap Bencana Tanah Longsor di Kecamatan Bantarkawung Kabupaten Brebes. Majalah Geografi Indonesia, 26(1), 80-97.

Fruhling, A., Tyser, K., \& Vreede, G. De. (2005). Experiences with Extreme Programming in Telehealth : Developing and Implementing a
Biosecurity Health Care Application, 00(C), 110.

Iacob, I. (2008). Extreme Programming And Rational Unified Process - Contrasts Or Synonyms? Journal of Information Systems \& Opearitions Management, 2(1), 122-134. Retrieved from http://www.rebe.rau.ro/RePEc/rau/jisomg/ SU08/JISOM-SU08-A12.pdf

Ningtyas, B. A. (2015). Pengaruh Pengetahuan Kebencanaan Terhadap Sikap Kesiapsiagaan Warga Dalam Menghadapi Bencana Tanah Longsor Di Desa Sridadi Kecamatan Sirampog Kabupaten Brebes Tahun 2014. Universitas Negeri Semarang.

Nuryanto, H. D. (2016). Sistem Informasi Bencana. Retrieved January 18, 2018, from https://republika.co.id/berita/koran/opinikoran/16/12/09/ohwuc815-sisteminformasi-bencana

Pressman, R. S. (2010). Software Engineering: A Practitioner's Approach (Seventh Ed). New York: MCGraw-Hill.

Raharjo, B. S. (2009). Kerentanan Medan Terhadap Longsoran di Kecamatan Banjarharjo Kabupaten Brebes. Universitas Negeri Semarang.

Riyanto, M. A. (2017, October). Musim Hujan Datang, Brebes Utara Rawan Banjir, Brebes Selatan Rawan Longsor. Tribunnews.Com. Retrieved from http://jateng.tribunnews.com/2017/10/09/ musim-hujan-datang-brebes-utara-rawanbanjir-brebes-selatan-rawan-longsor

Sasongko, A. (2016). Sistem Informasi Geografis Berbasis Web Untuk Pemetaan Jalan dan Bangunan (Studi Kasus: Bidang Tata Ruang Dinas Pekerjaan Umum Kabupaten Kubu Raya). Jurnal Khatulistiwa Informatika, 4(1), $1-12$.

Sinambela, L. P., Rochadi, S., Ghazali, R., Muksin, A., Setiabudi, D., Bima, D., \& Syaifudin. (2010). Reformasi Pelayanan Publik: Teori, Kebijakan dan Implementasi (Cetakan ke). Jakarta: Bumi Aksara.

Supriyatna, A. (2018). Metode Extreme Programming Pada Pembangunan Web Aplikasi Seleksi Peserta Pelatihan Kerja. Jurnal Teknik Informatika, 11(1), 1-18. 
Tayubi, K. (2018). Delapan Jenis Bencana Mengancam Wilayah Brebes. Retrieved January 11, 2018, from https://nusantara.medcom.id/jawatengah/peristiwa-jateng/0Kvq1eYk-delapanjenis-bencana-mengancam-wilayah-brebes

Undang-Undang Republik Indonesia No. 25 Tahun 2009 Tentang Pelayanan Publik. (n.d.).

Warjiyono, W., Aji, S., \& Permesti, T. I. (2018). Laporan Penelitian Dosen Yayasan. Jakarta. 